\title{
GERAKAN DONASI 3.000 MASKER KAIN DAN EDUKASI PENGGUNAAN MASKER KAIN DALAM UPAYA MENEKAN PENYEBARAN COVID-19
}

\author{
Vidila Rosalina1, Iin Nurniamah'2, Endah Yana ${ }^{3}$ \\ 1Teknik Informatika, Universitas Serang Raya \\ 2Jurusan Tata Busana, Alumni SMKN 3 Malang \\ 3Jurusan Tata Busana, Alumni SMKN 3 Malang \\ Email: vidila.suhendarsah@gmail.com
}

\begin{abstract}
In April 2020, almost all regions in Indonesia imposed Large Scale Social Restrictions due to the COVID-19 pandemic. Even though there are mobility restrictions, that doesn't mean everyone can just ignore health protocols. Masks are an item that must be worn by anyone when doing activities outside the home. Although the production of masks has increased, not a few Indonesians are still having trouble obtaining them. Departing from this problem, this service activity is to educate the use of effective cloth masks and donate 3,000 cloth masks to help provide masks for some residents of Malang and Serang districts who are less fortunate. In the first stage, Lecturers of the Faculty of Technology, Serang Raya University, in collaboration with alumni of SMKN 3 Malang majoring in fashion, made 3,000 cloth masks to help provide cloth masks for the community. This community service initiative aims to educate the public on the importance of using cloth masks that are effective in suppressing the spread of the COVID19 virus.
\end{abstract}

Keywords: Cofid-19, Cloth Masks, Mask Donation, Mask Use Education.

\begin{abstract}
Abstrak
Pada bulan April 2020, hampir semua daerah di Indonesia memberlakukan Pembatasan Sosial Berskala Besar (PSBB) karena pandemi COVID-19. Meski ada pembatasan mobilitas, bukan berarti semua orang bisa mengabaikan protokol kesehatan begitu saja. Masker menjadi benda yang wajib dikenakan oleh siapa pun saat beraktivitas di luar rumah. Meski produksi masker meningkat, tak sedikit warga Indonesia yang masih kesulitan memperolehnya. Berangkat dari permasalahan ini, maka kegiatan pengabdian ini yaitu edukasi penggunaan masker kain yang efektif dan mendonasikan 3.000 masker kain untuk membantu penyediaan masker bagi sebagian warga kabupaten Malang dan kabupaten Serang yang kurang mampu. Pada tahap pertama, Dosen Fakultas Teknologi Universitas Serang Raya bekerjasama dengan alumni SMKN 3 Malang jurusan tata busana membuat 3.000 masker kain untuk membantu penyediaan masker kain bagi masyarakat. Inisiatif kegiatan pegabdian masyarakat ini bertujuan untuk mengedukasi masyarakat akan pentingnya penggunaan masker kain yang efektif dalam menekan penyebaran virus COVID-19.
\end{abstract}

Kata Kunci: Cofid-19, Donasi Masker, Masker Kain, Edukasi Penggunaan Masker. 


\section{PENDAHULUAN}

Di saat pandemi, masker menjadi benda yang wajib dikenakan oleh siapa pun saat beraktivitas di luar rumah. Meski produksi masker meningkat, tak sedikit warga Indonesia yang masih kesulitan memperolehnya. Masker bermanfaat untuk membantu mencegah penularan bermacam-macam penyakit, seperti influenza, batuk, pilek, ISPA, dan sindrom pernapasan ringan dan akut atau Severe Acute Respiratory Syndrome. Jadi, pemakaian masker menjadi salah satu cara paling baik agar kita tidak mudah menularkan penyakit dan tertular penyakit. Masker harus digunakan secara benar agar bisa membantu mencegah virus COVID-19 menyebar melalui cairan yang keluar saat bersin ataupun batuk.

Dalam laporan ilmiah terbarunya, CDC meninjau bukti epidemiologi dan observasi tentang penggunaan masker, serta penyebaran virus corona. Mereka melakukan studi terhadap 124 rumah tangga di Beijing, China, di mana setidaknya satu orang memiliki kasus Covid-19 yang terkonfirmasi. Seperti yang sudah dilaporkan, ketika semua orang di rumah memakai masker sebelum orang yang terinfeksi mulai menunjukkan gejala, risiko penularan berkurang hingga 79 persen. Studi lain pada 1.000 orang yang melakukan kontak dengan kelompok yang terinfeksi di Thailand juga menjadi sorotan CDC. Hasil studi tersebut menyimpulkan bahwa kelompok orang yang disiplin menggunakan masker memiliki risiko 70 persen lebih rendah terinfeksi virus dibandingkan dengan kelompok orang yang tidak menggunakan masker.

Gugus Tugas Percepatan Penanganan Covid-19 dan CDC menyarankan pemakaian masker kain bagi masyarakat umum ketika beraktifitas di luar rumah ataupun ketika bersosialisasi dengan orang lain. Pemakaian masker sangan direkomendasikan di saat situasi yang menyulitkan untuk penerapan aturan jaga jarak fisik (physical distancing), seperti di saat berbelanja di pasar, dan saat bepergian menggunakan angkutan umum. WHO menganjurkan supaya negara-negara yang terkena dampak pandemi COVID-19 untuk merekomendasikan penggunaan masker non-medis bagi warganya, termasuk masker kain. Penggunaan masker kain dianjurkan karena masker medis lebih dibutuhkan oleh tenaga kesehatan. WHO sendiri juga membuat peratutan tentang kapan, siapa dan bagaimana memakai masker kain yang benar agar efektk menekan penyebaran virus COVID-19, antara lain yaitu:

1) Ketika mengalami gejala influenza, batuk dan pilek

2) Ketika berada di zona yang terpapar COVID-19, misalnya tinggal satu rumah dengan pasien yang sedang dalam pengawasan atau orang yang sedang dalam pemantauan

3) Menjaga kebiasaan cuci tangan di setiap kesempatan dengan sabun atau hand sanitizer / penyanitasi tangan.

4) Menggantinya masker dengan yang baru sesuai dengan rekomendasi lama pemakaian masker yan aman.

Syarat penggunaan masker kain agar efektif, adalah sbb :

1) Masker kain hanya boleh digunakan secara terus-menerus selama 4 jam. Setelah 4 jam masker kain harus segera dilepaskan untuk dicuci dan diganti dengan masker kain yang bersih. karena, bahan kain lebih gampang ditembus oleh virus COVID-19 dibandingkan dengan masker medis.

2) Masker kain harus digunakan secara pas dari atas hidung hingga dagu dan kedua sisi wajah kiri dan kanan.

3) Masker kain harus dilengkapi dengan tali pengikat yang dapat diikatkan ke belakang kepala atau tali karet yang dipasang di kedua telinga.

4) Masker kain harus terdiri dari beberapa lapis kain, minimal sebanyak dua lapis. 
5) Masker kain harus berbahan yang kuat, tidak mudah rapuh atau rusak saat dicuci dan disetrika.

6) Masker kain sebaiknya berbahan anti air atau bahan yang tahan terhadap cairan.

7) Masker kain harus tetap memperhatikan pengguna agar dapat bernapas dengan baik dan mudah.

8) Sebelum mengenakan masker kain, cuci tangan atau memakai hand satitizer terlebih dahulu.

9) Masker kain jangan terlalu sering disentuh, apalagi menurunkannya hingga ke dagu.

10) Melepaskan masker dengan cara yang benar, yaitu dengan membuka tali atau karetnya langsung dengan hati-hati. (Sari, 2020)

Kegiatan pengabdian masyarakat ini selain melakukan donasi 3.000 masker kain, juga mengedukasi masyarakat bagaimana penggunaan masker kain yang efektif agar dapat terhindar dari penularan COVID-19.

\section{METODE PELAKSANAAN}

Untuk mengantisipasi permasalahan terbatasnya kesediaan masker, digunakan dua metode pendekatan seperti metode yang pernah dilakukan pada kegiatan pengabdian pada masyarakat sebelumnya yaitu Sosialisasi Manfaat E-CRM Bagi UMKM (Rosalina V, 2018) dan Gerakan Donasi 5.000 buku (Rosalina V, 2019), yaitu:

Metode pertama, yaitu metode pendekatan Kaji-Tindak (Action-Research) Kleiman et al. (2001). Metode kaji-tindak partisipatif, adalah metode dilakukan dengan berkerjasama antara tim pengabdian masyarakat dan pemilik masalah. Ketergantungan saling menguntungkan antara tim terletak pada pemahaman bersama terhadap masalah yang harus dipecahkan, keterampilan, pengalaman, dan kompetensi; agar proses realisasi program dan pengembangannya dapat tercapai dengan optimal. Kaji tindak partisipatif merupakan hibrid antara riset (research) dan tindakan (action) yang dikerjakan secara partisipatif guna menghasilkan masker kain yang sesuai standar dan persyaratan.

Metode kedua, adalah metode peer-coaching, adalah metode yang dikerjakan dengan tujuan untuk dapat menyampaikan informasi, pengetahuan dan pesan yang dilakukan oleh teman sejawatnya. Dalam hal ini tim pengabdian masyarakat selaku teman sejawat menyampaikan edukasi pengetahuannya kepada masyarakat tentang bagaimana penggunaan masker kain yang efektif.

Tahapan program-program yang dikerjakan pada pengabdian masyarakat ini sebagai solusi permasalahan yang terjadi masyarakat adalah:

1) Melakukan kajian literatur terkait dan studi lapangan awal sebagai studi pendahuluan terkait pembuatan masker kain yang sesuai atandar dan persyaratan.

2) Melakukan survey dan observasi terhadap warga terkait pengetahuan penggunaan masker kain yang efektif.

3) Melakukan tindakan pemecahan masalah keterbatasan ketersediaan masker di pasaran dengan melakukan gerakan donasi 3.000 masker kain.

4) Melakukan tindakan pemecahan masalah kurangnya pengetahuan masyarakat terhadap pemakaian masker kain yang efektif dalam menekan penyebaran COVID-19.

\section{HASIL DAN PEMBAHASAN}

Gerakan Donasi 3.000 Masker Kain Dan Edukasi Pemakaian Masker Kain bertujuan untuk membantu mengurangi penyebaran COVID-19 ini dilakukan di 5 Desa, 2 Kabupaten dan 2 Provinsi. Pembuatan masker kain dilakukan di bulan Maret 2020 oleh para alumni SMKN 3 Malang. Gerakan donasi masker kain dan edukasi penggunaan masker kain yang efektif dilakukan pada tanggal 14 April 2020 - 24 Juni 2020. 
Tabel 1.Pembagian Masker Kain

\begin{tabular}{clr}
\hline No. & Desa & Jumlah \\
\hline 1. & Wendit & 500 \\
2. & Pakis & 500 \\
& Kembar & \\
3. & Bunut & 500 \\
4. & Harjatani & 1.000 \\
5. & Kelapa & \\
& Kurung & 500 \\
\hline & Jumlah & $\mathbf{3 . 0 0 0}$ \\
\hline
\end{tabular}

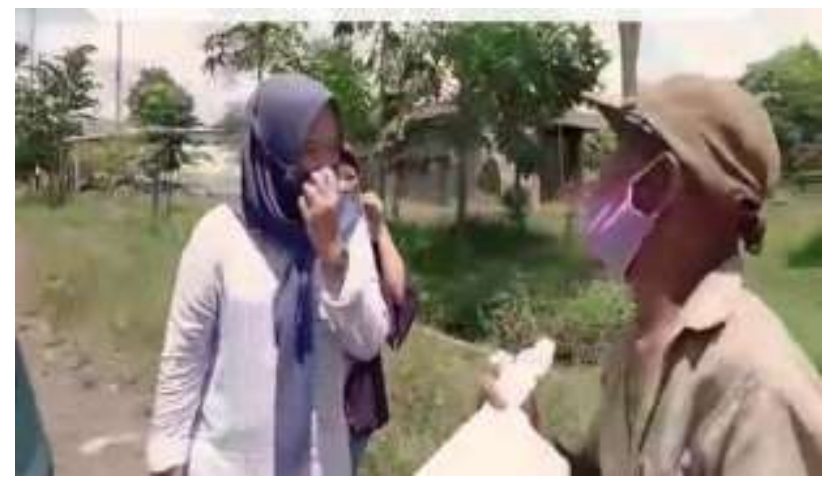

Gambar 1. Edukasi Penggunaan Masker Kain Warga Desa Wendit Kabupaten Malang

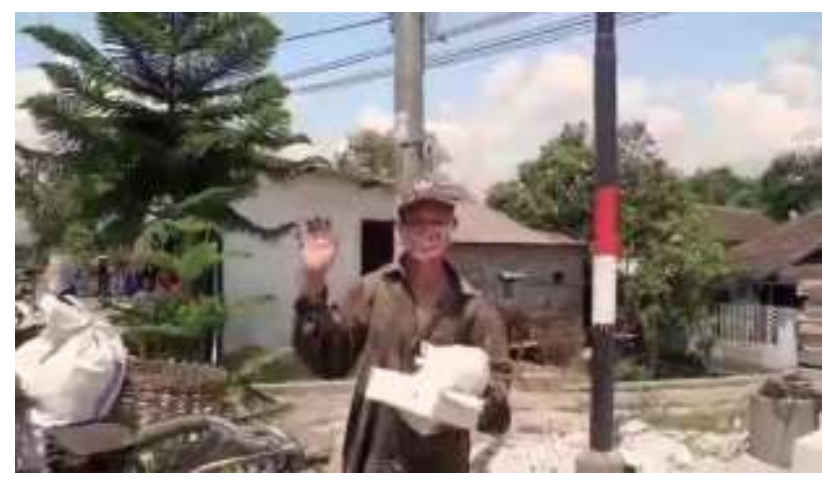

Gambar 2. Pembagian Masker Kain Warga Desa Wendit Kabupaten Malang

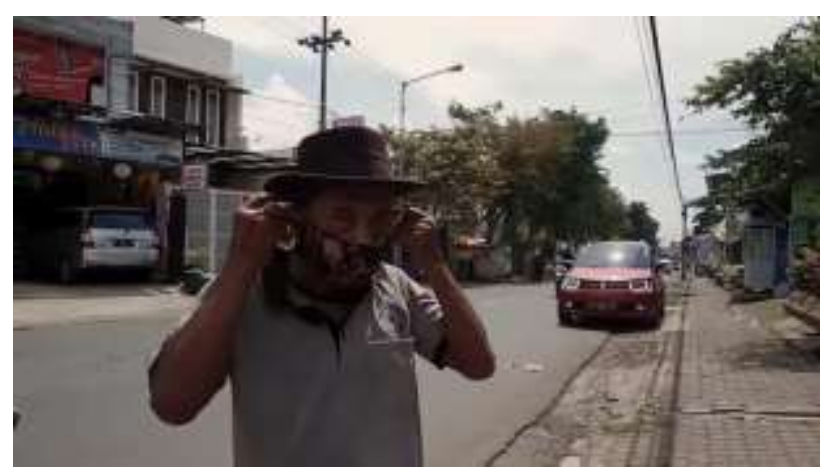

Gambar 3. Edukasi Penggunaan Masker Kain Yang Efektif dan Pembagian Masker Kain Warga Desa Harjatani Kabupaten Serang

Sosialisasi dilakukan secara face to face oleh tim edukasi yang terdiri dari 100 relawan baik dari kabupaten malang maupun kabupaten serang. Edukasi penggunaan masker kain agar efektif, yang telah disampaikan ke masyarakat yaitu :

1) Masker kain hanya boleh digunakan secara terus-menerus selama 4 jam. Setelah 4 jam masker kain harus segera dilepaskan untuk dicuci dan diganti dengan masker kain yang bersih. karena, bahan kain lebih gampang ditembus oleh virus COVID-19 dibandingkan dengan masker medis.

2) Masker kain harus digunakan secara pas dari atas hidung hingga dagu dan kedua sisi wajah kiri dan kanan.

3) Sebelum mengenakan masker kain , cuci tangan atau memakai hand satitizer terlebih dahulu.

4) Masker kain jangan terlalu sering disentuh, apalagi menurunkannya hingga ke dagu.

5) Melepaskan masker dengan cara yang benar, yaitu dengan membuka tali atau karetnya langsung dengan hati-hati.

\section{Ucapan Terima Kasih}

Terimakasih tak terhingga kami ucapkan kepada para donatur, baik berupa pendanaan maupun pengadaan bahan-bahan masker kain. Terimakasih sebesar-besarnya kepada para alumni SMKN 3 Malang atas waktu dan tenaganya dalam pembuatan masker kain. Terimakasih juga kepada tim relawan yang telah membantu mengedukasi masyarakat bagaimana menggunakan masker kain yang efektif dan membagikan masker kain kepada warga yang membutuhkan.

\section{KESIMPULAN DAN SARAN}

\section{Kesimpulan}


Kegiatan edukasi penggunaan masker dan donasi 3.000 masker ini merupakan langkah kecil pengabdian masyarakat yang bertujuan bemberi inspirasi kepada banyak orang agar dapat bersama-sama berpola pikir positif, saling menolong dalam kebaikan dan tetap menjaga diri sendiri dengan tetap konsisten mematuhi protokol kesehatan dan menggunakan alat perlindungan secara efektif. Kegiatan ini juga merupakan cara mengingatkan bahwa masyarakat Indonesia perlu bersatu dan saling menguatkan dalam menghadapi masa pandemi ini.

\section{Saran}

Perlunya kegiatan pengabdian masyarakat dengan kolaborasi yang berkelanjutan dari seluruh komponen masyarakat agar bersinergi menyukseskan program pemerintah untuk menekan penyebaran virus corona. Kegiatan ini tidak akan berhasil jika dilakukan sendiri maka itu perlu adanya komitmen, kerjasama dan sinergi dari semua kompone terkait secara berkelanjutan.

\section{DAFTAR REFERENSI}

Rosalina, Vidila, dkk. (2015). E-Pedagogis Bagi Tutor Untuk Meningkatkan Kualitas Pembelajaran Di Pusat Kegiatan Belajar Masyarakat (PKBM), Prosiding PKM-CSR 2015, Konferensi Nasional Pengabdian Kepada Masyarakat - Corporate Social Responsibility, 22-23 Oktober 2015.

Rosalina, Vidila, dkk. (2017). Sosialisasi Manfaat E-CRM dalam Upaya Meningkatkan Retensi Pelanggan UMKM Cilegon. Jurnal Pengabdian Masyarakat Wikrama Parahita Vol 1 No 1, November 2017.

Rosalina, Vidila, dkk. (2019). Gerakan Donasi Buku Dalam Upaya Membangun Budaya Literasi Tahap 1. Seminar Hasil Pengabdian Kepada Masyarakat (SEMBADHA) PKNSTAN 2019.
Rosalina, Vidila, dkk. (2019). Pengenalan Aplikasi Electronic Customer Relationship Management (E-CRM) Pada Pelaku Usaha Mikro Kecil Dan Menengah (UMKM) Desa Harjatani. Jurnal KUAT: Keuangan Umum Dan Asuransi Terapan Vol 1 No 2.

Rosalina, Vidila, dkk. (2019). Pengenalan Perangkat Lunak E-CRM UMKM Untuk Peningkatan Loyalitas Pelanggan Usaha Mikro Kecil dan Menengah di Desa Kelapa Kurung. EKONOMIKAWAN: Jurnal Ilmu Ekonomi dan Studi Pembangunan Vol 19 No 2.

Rosalina, Vidila, dkk, (2020). Gerakan Donasi Buku Dalam Upaya Membangun Budaya Literasi Tahap 2. BANTENESE: Jurnal Pengabdian Masyarakat Vol 2 No 2.

Sari, Fitri Rahayu. (2020). Efektifitas Penggunaan Masker Kain Dalam Mencegah Covid-19. Primaya Hospital. https://primayahospital.com/paru/masker -kain-corona/

CDC. (2020). Use Masks to Slow the Spread of COVID-19.

https://www.cdc.gov/coronavirus/2019ncov/prevent-getting-sick/diy-cloth-facecoverings.html

WHO. (2020). Corona virus disease (COVID-19) advice for the public: When and how to use masks.

https://www.who.int/emergencies/disease s/novel-coronavirus-2019/advice-forpublic/when-and-how-to-use-masks

WHO. (2020). Advice on the use of masks in the context of COVID-19. https://apps.who.int/iris/rest/bitstreams/ $1274280 /$ retrieve 